\title{
Manual Therapy Techniques and their Effectiveness on Improving Posture in Adults: A Narrative Review of the Literature
}

\author{
Emily Dudek and Lynne C Hughes* \\ Department of Physical Therapy, the University of Texas Medical Branch, Galveston, Texas, USA
}

${ }^{*}$ Corresponding author: Lynne Hughes, PT, PhD, OCS, MTC, Associate Professor, Department of Physical Therapy, the University of Texas Medical Branch, Galveston, Texas, USA; Phone: 4097729519; Fax: 4097471613; Email: lyhughes@utmb.edu

Received: March 29, 2019; Accepted: April 09, 2019; Published: April 12, 2019;

\begin{abstract}
Objective: To review the literature regarding the use of manual therapy techniques and their effectiveness on improving posture in adults.

Background: Hyperkyphosis of the upper spine is a condition that increases with age and leads to decreased pulmonary function, balance, and muscle strength. Numerous reviews have looked at the effect of therapeutic exercise, but few have examined the effects of manual therapy techniques on hyperkyphotic posture.

Methods: Three electronic databases were searched. All of the studies published in English that have considered the effects of manual therapy (including soft tissue mobilization and joint mobilizations) on posture were included in this review ( 7 randomized controlled trials, 4 case studies, and 1 preliminary trial).

Results: Of the 7 randomized controlled trials, 2 studies utilized soft tissue mobilizations, 3 used joint mobilizations of the cervical and/or thoracic spine, and 2 used both techniques. 3 of the studies also combined the manual therapy treatment with other techniques, including stretching, taping, and therapeutic exercise. Outcome measures varied and included thoracic index, inclinometer or kyphometer readings, and goniometric measurements. All but one of the randomized studies found manual therapy to be an effective intervention for improving posture. Of the 4 case reports, each used a different manual therapy approach, but all were either joint mobilizations of the spine or shoulder girdle or myofascial release. 3 of the reports combined the manual therapy with other types of treatment, including proprioceptive neuromuscular facilitation (PNF) and therapeutic exercise. Postural alignment was found to improve in all of the cases, though this was measured subjectively via photo or visual analysis by 3 of the studies, while 1 study used goniometric measurements.
\end{abstract}

The final study included was a non-randomized preliminary study using an ATM2 machine to assist with joint mobilizations using Mulligan's mobilization-with-movement concept. This study found mobilizations to be effective for improving posture as assessed by photographic analysis.

Conclusion: Of the 12 studies reviewed, 11 demonstrated an improvement in posture after treatment with manual therapy techniques. This indicates that manual therapy is a promising treatment for a condition that affects a large proportion of individuals as they age.

\section{Introduction}

As people age, their thoracic spine tends to undergo an increase in angle of kyphosis, or forward rounding of the back, which can affect both the cervical and lumbar spine $[1,2]$. While the normal values for angle of thoracic kyphosis in adults aged $20-39$ are $27.66^{\circ}$ for males and $27.62^{\circ}$ for women, these values increase more in women after age 40 [3]. The mean value for women aged $60-69$ is $44.86^{\circ}$, compared with $34.67^{\circ}$ for males [3].

Hyperkyphosis is defined as a value greater than $40^{\circ}$ and such a condition leads to decreased pulmonary function, balance, and muscle strength $[4,5]$. Because of these potentially harmful consequences, an intervention must be sought for treatment to prevent or correct hyperkyphosis in older adults.
The etiology behind this increase in kyphosis with age is multifactorial, and many of the underlying causes are linked to one another. It has long been assumed that vertebral fractures related to osteoporosis play the most important role in determining whether or not someone develops hyperkyphosis. While having multiple vertebral fractures (especially thoracic anterior wedge fractures) may increase the risk of hyperkyphosis, it is far from the only cause. Other factors commonly associated with aging include degenerative disc disease, loss of proprioception, muscle weakness or atrophy, and ligamentous degeneration. Muscle weakness, especially in the spinal extensors, often leads to habitually poor posture, which increases spinal kyphosis $[1,4]$.

Treatments that have been studied to prevent and treat hyperkyphosis include exercise, bracing, taping, and manual therapy [4]. Therapeutic exercise is the most commonly studied intervention 
for poor posture and hyperkyphosis, and it has shown promising results as a conservative treatment $[1,4]$. Manual Therapy (MT) is a technique used to treat various musculoskeletal conditions including but not limited to adhesive capsulitis [6], subacromial impingement syndrome [7], and osteoarthritis [8]. Treatment using manual therapy techniques has not been studied as extensively as the other therapeutic modalities, and therefore a literature review on the topic was conducted to determine if it is a viable treatment for kyphotic posture.

\section{Methods}

\section{Selection Criteria}

Studies included randomized controlled trials, nonrandomized trials, and case studies and the search was restricted to papers published in English. Because of the fact that poor posture is often linked to other conditions and the limited number of studies conducted on the topic, studies including patients with various orthopedic conditions such as osteoporosis, ankylosing spondylosis, cystic fibrosis, neck pain, and scoliosis were included in the search. Studies focusing on neurological disorders were not included in the search.

Studies where at least one application of manual therapy (including joint mobilization, soft tissue techniques, or massage) was administered were included. Body parts receiving the therapy included one or more of the following areas: shoulder girdle, pectoral muscles, cervical spine, or lumbar spine. Studies that combined MT with other forms of therapy were also included if the MT technique was an independent variable. Age of study participants was limited to adults (over 18) because both the causes and the prognosis of hyperkyphosis may differ in children, whose bodies are still developing. Only studies that compared the posture of patients before and after treatment were included in the search.

\section{Search Strategy}

A search was conducted for published articles that answer the question: do manual therapy techniques improve posture in adults? An electronic search of databases including Ovid, PubMed, and Web of Science was conducted through August 2016. Search terms included a variety of phrases related to posture and MT. The summary of search terms can be seen in table 1, and common strings included "posture", "manual therapy", "musculoskeletal manipulations", "spinal mobilization", "soft tissue mobilization", and "kyphosis". The first search was limited to ages 65 and older, but subsequent searches were expanded because there was found to be limited research in this age group. Supplementary searches were conducted by screening reference lists of relevant articles for additional studies.

\section{Data Synthesis}

7 RCTs $(n=236)$ from 1897 hits on database searches and reference list screenings were included. 4 case reports and 1 nonrandomized intervention were also included and will be analyzed separately.

Manual therapy interventions included soft tissue mobilization [5, $6,10]$, myofascial release [11], thoracic spine mobilizations [5, 11-13], cervical joint mobilizations [13, 14], and rib mobilizations [11]. MT was used in isolation $[10,13,14]$, or in combination with stretching
[9], exercise $[5,11,12]$, taping $[5,12]$, or postural reeducation [11]. Controls included no Physical Therapy (PT) [5, 1012], PT without mobilizations [11], passive light manual placebo touch and pectoralis major stretching [9], or cervical mobilization only [13, 14].

Table 1. Search Strings

\begin{tabular}{|c|c|c|c|c|}
\hline Database & Date & Search Terms & Hits & $\begin{array}{c}\text { Articles } \\
\text { Used }\end{array}$ \\
\hline Ovid & $9 / 21 / 2016$ & $\begin{array}{l}\text { "posture" AND } \\
\text { "musculoskeletal } \\
\text { manipulations" (limited to } \\
\text { "all aged } 65 \text { and over" OR } \\
\text { "aged } 80 \text { and over") }\end{array}$ & 76 & 1 \\
\hline Ovid & $9 / 21 / 2016$ & $\begin{array}{l}\text { "posture" and } \\
\text { "musculoskeletal } \\
\text { manipulations" and "physical } \\
\text { therapy modalities" }\end{array}$ & 371 & 4 \\
\hline PubMed & $9 / 26 / 2016$ & $\begin{array}{l}\text { "physical therapy modalities" } \\
\text { AND "musculoskeletal } \\
\text { manipulations" OR } \\
\text { "manual therapy" OR } \\
\text { "spinal manipulation" OR } \\
\text { "manipulation, osteopathic" } \\
\text { AND "posture" }\end{array}$ & 1152 & 4 \\
\hline $\begin{array}{l}\text { Web of } \\
\text { Science }\end{array}$ & $9 / 26 / 2016$ & $\begin{array}{l}\text { "posture" and "manual } \\
\text { therapy" OR "spinal } \\
\text { mobilization" OR "soft } \\
\text { tissue mobilization" AND } \\
\text { "kyphosis" }\end{array}$ & 298 & 2 \\
\hline $\begin{array}{l}\text { Reference } \\
\text { list review }\end{array}$ & $9 / 29 / 2016$ & $\begin{array}{l}\text { "posture" AND "physical } \\
\text { therapy" OR "manual } \\
\text { therapy" }\end{array}$ & 3 & 3 \\
\hline
\end{tabular}

Treatment length varied with one study assessing the outcomes after a single MT session (Wong et al), one with 6 sessions over 6 weeks [11], one with 10 sessions over 10 weeks [5], two with 12 sessions over 4 weeks [13, 14], one with 16 sessions over 2 weeks [10], and one study with 18 sessions over 12 weeks [12].

Outcome measures used to assess changes in posture also varied considerably between studies, with each one using differing techniques. One study measured the distance from the acromion to the table, a process that has been used in several previous studies to measure rounded shoulder posture [9]. Three studies measured thoracic kyphosis, two using inclinometers [5, 12], and the other finding thoracic index by using a flexible ruler to determine the thoracic curve in the sagittal plane [11]. One study measured both cervical kyphosis using a pair of compasses and a ruler as well as thoracic and lumbar kyphosis using a kyphometer [10]. Two studies measured cervical lordosis using the absolute rotation angle [14], or cranial vertical angle and cranial rotation angle [13].

6 of the 7 randomized trials found an improvement in posture with MT techniques versus control. The one study that showed no difference between groups compared MT to no PT treatment, with 10 sessions over 10 weeks and used thoracic kyphosis as the primary outcome measure [5]. The patient population in this study was one of the two RCTs with a mean age above 60 years, focusing on osteoporotic patients with vertebral fracture. This study utilized 
passive accessory central posterior-anterior mobilization of the thoracic spine with 5 movements at each level and 2 reps, applying a grade II or III mobilization and MT was used in combination with exercise and taping techniques [5].

For the case studies and nonrandomized trial, approaches to MT that were used included cervical [15], scapular [15], lumbar [16], and lumbosacral mobilizations [17], myofascial release [18], and the use of an ATM2 machine to assist with thoracic and lumbar mobilizationswith-movement [19].

Two of the studies did not combine MT with other forms of treatment $[18,19]$. The other 4 studies combined MT with therapeutic exercise [17], breathing and therapeutic exercise [15], or Proprioceptive Neuromuscular Facilitation (PNF) [16]. The PNF technique used was described as dynamic reversal of antagonist technique of the shoulder [16].

Treatment was also wide-ranging in both duration and frequency of the treatment. The shortest treatment duration was 4 weeks, with 3 studies choosing this time frame but varying the number of sessions with either 8 [19], 11 [15], or 12 [16]. One study chose a 6-week time frame with 12 sessions [18]. The final study chose a 16-week duration, with 9 sessions [17].

Outcome measures to demonstrate changes in posture that were used included visual assessment [15, 18, 19], video assessment [17], and angle of spinal curvature using a spinal mouse [16]. An additional case study did not specifically look at posture as an outcome measure, but rather function (assessed with the Oswestry), quality of life (assessed with the QUALEFFO), and pain (McGill Pain Scale) [20]. This study was not included as part of the review but is mentioned here because it was looking for adverse effects of manual therapy on a patient with osteoporosis, which is an important group to consider for the assessment of older adults with kyphosis.

All 4 of the case reports measuring posture as an outcome measure showed improvement after treatment with MT, and the case report that measured quality of life, pain, and function also showed no adverse effects with MT treatment. The nonrandomized trial likewise showed similar improvements in posture after spinal mobilization treatments [20].

\section{Discussion}

The MT approaches varied between studies in the RCT group. The one study that utilized Soft Tissue Mobilization (STM) performed 3 minutes of strumming perpendicular to the pectoralis minor muscle belly [9]. Of the studies utilizing joint mobilizations of the spine, only one described using a grade II or III mobilization [5]. One study described the number of repetitions as 10-15 free passive angular movements of thoracic spine with end-range positions held for 5 seconds or as tolerated [12]. The next study gave a limited description of active angular and passive mobility exercises in 4 directions (flexion, extension, lateral flexion, and rotation) [10]. In the study by Gong et al, passive motion analysis was done on the cervical spine and then mobilization was applied by checking mobility in the joint of interest while preventing motion in surrounding joints [14]. The study by Lee et al applied passive extension mobilizations at end range for the cervical spine joints and for the thoracic spine "the therapist pushed hard at the end range to increase mobility" [13]. The final study did not include details on how the manual therapy was applied [11].

For the case study group, one case described using grade III mobilizations of the lumbar spine [16], while the other three studies utilizing mobilizations described only the joints at which the techniques were applied $[15,17]$, or the number of sets and repetitions [19]. The final study in this group used myofascial release techniques applied for 90-120 seconds at each muscle group [18].

The wide ranging descriptions of the manual therapy techniques used in each of these studies points to the need for more precise documentation in future studies. The details provided in the text of a study should allow another researcher to replicate the treatment protocol, which means that manual mobilizations should not only be described in detail, but the grade(s) of pressure used should also be noted.

While all of the RCTs utilized physical therapists to administer MT intervention, two studies specifically used certified Orthopedic Clinical Specialist physical therapists $[9,13]$. Only one other RCT mentioned training the therapists involved in the study to perform interventions in a specified manner [5]. The case study authors were less descriptive of the physical therapists administering treatment, but in the studies where the PT credentials were not explicitly mentioned, therapy was conducted by the study author. One study utilized MFR treatment by a licensed massage and bodywork therapist [18], while another used a PT that had completed a Kaltenborn-Evjenth Orthopedic Manual Therapy (KEOMT) spine advanced course [16].

The number of physical therapy sessions and study length for both the RCT group and the case study group was about equal, with an average of 10.7 and 10.4 manual therapy sessions. The number of weeks over which the sessions occurred was also very similar, with an average of 7.2 weeks for the RCT group and 7.3 weeks for the case study group. There was greater variance between studies, however, with most studies either lasting one month or about 3 months. The shorter, one month time frame is more likely to be clinically realistic. As far as number of sessions goes, a Dutch study of 41 PT practices found that there was an average of 9.9 treatment sessions among patients with a diagnosis of low back pain [21]. Therefore, having an average of 10.5 treatment sessions for the studies listed here is not unrealistic, but this number could vary depending on the laws in the particular country of treatment.

In an assessment of the outcome measures used to measure the postural improvements, each of the randomized trials utilized highly reliable measurement tools. The distance from the posterior border of the acromion to the table used by Wong et al was shown to have a reliability of $0.88-0.94$, and this measurement is also easy to learn and replicate [22]. The spinal mouse used by Bautmanns et al and the Debrunner kyphometer used by Widberg et al were both shown to have a both a very high inter-rater and intra-rater reliability [23]. The rotation angle to measure cervical posture used by Gong et al and Lee et al was also shown to have a high Interclass Correlation Coefficient (ICC) [24]. And finally, the thoracic index (measured using a flexible ruler) used by Sandsund et al had an ICC of 0.94 . The validity of the measurement tools used in these studies further increases the evidence that posture can be improved by manual therapy techniques. 
Table 2. RCT: Study Characteristics

\begin{tabular}{|c|c|c|c|c|c|c|c|c|}
\hline $\begin{array}{l}\text { Author, } \\
\text { Year }\end{array}$ & MT Approach & $\begin{array}{l}\text { Other } \\
\text { Treatment }\end{array}$ & $\begin{array}{c}\text { Patient } \\
\text { Population }\end{array}$ & $\begin{array}{l}\text { Mean } \\
\text { age }\end{array}$ & Study Size & $\begin{array}{l}\text { Treatment } \\
\text { Length }\end{array}$ & $\begin{array}{l}\text { Outcome } \\
\text { Measures }\end{array}$ & Results \\
\hline $\begin{array}{l}\text { Wong et } \\
\text { al, } 2009\end{array}$ & $\begin{array}{l}\text { Pectoralis minor } \\
\text { STM and self- } \\
\text { stretching }\end{array}$ & Yes - stretching & $\begin{array}{l}\text { Healthy patients } \\
\text { with rounded } \\
\text { shoulder posture } \\
\text { (RSP); } 40 \% \\
\text { female }\end{array}$ & 25.5 & $\begin{array}{l}\mathrm{n}=56 ; 31 \\
\text { experimental, } \\
25 \text { control }\end{array}$ & $\begin{array}{l}1 \text { session } \\
\text { with } 2 \text { week } \\
\text { follow-up }\end{array}$ & $\begin{array}{l}\text { RSP measuring } \\
\text { distance from } \\
\text { acromion to exam } \\
\text { table }\end{array}$ & $\begin{array}{l}\text { One session of pec minor } \\
\text { STM and self-stretching } \\
\text { significantly reduced RSP } \\
\text { for up to } 2 \text { weeks }\end{array}$ \\
\hline $\begin{array}{l}\text { Bautmans } \\
\text { et al, } 2010\end{array}$ & $\begin{array}{l}\text { Thoracic } \\
\text { spine manual } \\
\text { mobilizations }\end{array}$ & $\begin{array}{l}\text { Yes - taping, } \\
\text { exercise }\end{array}$ & $\begin{array}{l}\text { Elderly } \\
\text { postmenopausal } \\
\text { patients with } \\
\text { osteoporosis; } \\
100 \% \text { female }\end{array}$ & 76 & $\begin{array}{l}\mathrm{n}=38 ; 21 \\
\text { experimental, } \\
16 \text { control }\end{array}$ & $\begin{array}{l}18 \text { sessions } \\
\text { over } 12 \\
\text { weeks }\end{array}$ & $\begin{array}{l}\text { Thoracic } \\
\text { kyphosis using } \\
\text { Spinal Mouse } \\
\text { (hand-held } \\
\text { inclinometer) }\end{array}$ & $\begin{array}{l}\text { Thoracic kyphosis improved } \\
\text { significantly }\end{array}$ \\
\hline $\begin{array}{l}\text { Widberg et } \\
\text { al, } 2008\end{array}$ & $\begin{array}{l}\text { Self and manual soft } \\
\text { tissue mobilizations }\end{array}$ & No & $\begin{array}{l}\text { Patients with } \\
\text { ankylosing } \\
\text { spondylosis; } \\
100 \% \text { male }\end{array}$ & 35.8 & $\begin{array}{l}\mathrm{n}=32 ; 16 \\
\text { experimental, } \\
16 \text { control }\end{array}$ & $\begin{array}{l}8 \text { weeks; } 1 \\
\text { hr } 2 \mathrm{x} / \text { week }+ \\
\text { HEP }\end{array}$ & $\begin{array}{l}\text { Pair of } \\
\text { compasses and a } \\
\text { ruler (cervical); } \\
\text { Debrunner's } \\
\text { kyphometer } \\
\text { (thoracic \& } \\
\text { lumbar) }\end{array}$ & $\begin{array}{l}\text { Improved sagittal plane } \\
\text { posture in c-spine; improved } \\
\text { posture in neutral position } \\
\text { at t-spine }\end{array}$ \\
\hline $\begin{array}{l}\text { Gong et al, } \\
2015\end{array}$ & $\begin{array}{l}\text { Passive motion } \\
\text { analysis vs. regular } \\
\text { cervical joint } \\
\text { mobilization }\end{array}$ & No & $\begin{array}{l}\text { University } \\
\text { students with } \\
\text { postural deficits }\end{array}$ & 22.4 & $\begin{array}{l}\mathrm{n}=40 ; 20 \\
\text { experimental, } \\
20 \text { control }\end{array}$ & $\begin{array}{l}3 \mathrm{x} / \text { week for } 4 \\
\text { weeks }\end{array}$ & $\begin{array}{l}\text { Absolute rotation } \\
\text { angle - cervical } \\
\text { lordosis }\end{array}$ & $\begin{array}{l}\text { Decreased forward head } \\
\text { posture and improved } \\
\text { cervical lordosis and ROM }\end{array}$ \\
\hline $\begin{array}{l}\text { Sandsund } \\
\text { et al, } 2011\end{array}$ & $\begin{array}{l}\text { Mobilizations of rib } \\
\text { cage and t-spine; } \\
\text { myofascial release }\end{array}$ & $\begin{array}{l}\text { Yes }- \text { Alexander } \\
\text { technique, } \\
\text { regular PT }\end{array}$ & $\begin{array}{l}\text { Patients with CF; } \\
50 \% \text { female }\end{array}$ & 27 & $\begin{array}{l}\mathrm{n}=20 ; 10 \\
\text { experimental, } \\
10 \text { control }\end{array}$ & $\begin{array}{l}12 \text { weeks; } 6 \\
\text { weekly visits }\end{array}$ & $\begin{array}{l}\text { Thoracic index } \\
\text { - thoracic curve } \\
\text { in sagittal plane } \\
\text { using flexible } \\
\text { ruler }\end{array}$ & $\begin{array}{l}\text { Thoracic index decreased, } \\
\text { showing improvement }\end{array}$ \\
\hline $\begin{array}{l}\text { Lee et al, } \\
2012\end{array}$ & $\begin{array}{l}\text { Cervical and thoracic } \\
\text { mobilization vs } \\
\text { cervical mobilization } \\
\text { only (control) }\end{array}$ & No & $\begin{array}{l}\text { Patients with neck } \\
\text { pain and forward } \\
\text { head posture }\end{array}$ & Adults & $\begin{array}{l}\mathrm{n}=30 ; 15 \\
\text { experimental, } \\
15 \text { control }\end{array}$ & $\begin{array}{l}15 \min 3 x / \\
\text { week for } 4 \\
\text { weeks }\end{array}$ & $\begin{array}{l}\text { Cranial vertical } \\
\text { angle (CVA) and } \\
\text { cranial rotation } \\
\text { angle (CRA) }\end{array}$ & $\begin{array}{l}\text { CVA increased and CRA } \\
\text { decreased. Cervical }+ \\
\text { thoracic mobilizations are } \\
\text { more effective than cervical } \\
\text { alone. }\end{array}$ \\
\hline $\begin{array}{l}\text { Bennell et } \\
\text { al, } 2010\end{array}$ & $\begin{array}{l}\text { Soft tissue } \\
\text { massage, thoracic } \\
\text { mobilizations }\end{array}$ & $\begin{array}{l}\text { Yes - taping, } \\
\text { exercise }\end{array}$ & $\begin{array}{l}\text { Patients with } \\
\text { osteoporotic } \\
\text { vertebral fracture; } \\
85 \% \text { female }\end{array}$ & 66.2 & $\begin{array}{l}\mathrm{n}=20 ; 11 \\
\text { experimental, } \\
9 \text { control }\end{array}$ & $\begin{array}{l}10 \text { weeks; } 1 \mathrm{x} / \\
\text { week }+\mathrm{HEP}\end{array}$ & $\begin{array}{l}\text { Thoracic } \\
\text { kyphosis using } \\
\text { Dualer Electric } \\
\text { Inclinometer }\end{array}$ & $\begin{array}{l}\text { No difference between } \\
\text { groups }\end{array}$ \\
\hline
\end{tabular}

Table 3. Case Study: Study Characteristics

\begin{tabular}{|c|c|c|c|c|c|c|}
\hline Author & MT Approach & $\begin{array}{c}\text { Other } \\
\text { Treatment }\end{array}$ & $\begin{array}{c}\text { Patient } \\
\text { Characteristics }\end{array}$ & Treatment Length & Outcome Measures & Results \\
\hline Roehrig, 2006 & $\begin{array}{l}\text { Neurodevelopmental treatment- } \\
\text { cervical and scapular mobilization }\end{array}$ & $\begin{array}{l}\text { Yes - } \\
\text { breathing, } \\
\text { exercise }\end{array}$ & $\begin{array}{l}78 \text { year old female } \\
\text { with kyphosis and } \\
\text { osteoporosis }\end{array}$ & $\begin{array}{l}11 \text { visits over } 4 \text { weeks; } \\
\text { mobilizations began at } \\
\text { visit } 4\end{array}$ & $\begin{array}{l}\text { Visual assessment; } \\
\text { goniometric measure }\end{array}$ & $\begin{array}{l}\text { Posture } \\
\text { improved }\end{array}$ \\
\hline LeBauer et al, 2008 & Myofascial release & No & $\begin{array}{l}18 \text { year old female } \\
\text { with idiopathic } \\
\text { scoliosis }\end{array}$ & 6 weeks; 1 hr 2x/week & $\begin{array}{l}\text { Visual assessment via } \\
\text { grid photography }\end{array}$ & $\begin{array}{l}\text { Posture } \\
\text { improved }\end{array}$ \\
\hline Staes et al, 2011 & Lumbosacral manual therapy & Yes - exercise & 26 year old female & $\begin{array}{l}930 \text { min. sessions over } 4 \\
\text { months }\end{array}$ & $\begin{array}{l}\text { Forward head posture } \\
\text { and shoulder position } \\
\text { via video screening }\end{array}$ & $\begin{array}{l}\text { Postural } \\
\text { alignment } \\
\text { improved }\end{array}$ \\
\hline Park et al, 2014 & $\begin{array}{l}\text { Kaltenborn-Evjenth orthopedic } \\
\text { manual therapy (lumbar) }\end{array}$ & Yes - PNF & $\begin{array}{l}29 \text { year old female } \\
\text { with chronic LBP and } \\
\text { lumbar transitional } \\
\text { vertebra }\end{array}$ & 4 weeks $40 \mathrm{~min} .3 \mathrm{x} /$ week & $\begin{array}{l}\text { Angle of spinal } \\
\text { curvature }\end{array}$ & $\begin{array}{l}\text { Spinal } \\
\text { curvature } \\
\text { and ROM } \\
\text { increased }\end{array}$ \\
\hline *Lewis et al, 2014 & $\begin{array}{l}\text { ATM2 using Mulligan's } \\
\text { mobilization-with-movement } \\
\text { (thoracic and lumbar) }\end{array}$ & No & $\begin{array}{l}43 \text { patients aged } \\
14-63 \text { with mild-to- } \\
\text { moderate scoliosis; } \\
86 \% \text { female; mean } \\
\text { age } 43.5\end{array}$ & $\begin{array}{l}4 \text { week intervention } 2 \mathrm{x} / \\
\text { week }+ \text { HEP }\end{array}$ & $\begin{array}{l}\text { Visual assessment via } \\
\text { photography }\end{array}$ & $\begin{array}{l}\text { Posture } \\
\text { improved }\end{array}$ \\
\hline
\end{tabular}

*Not a case study but a preliminary trial 
In the RCT by Bennell et al, while no change was shown in posture, other outcome measures such as pain, physical function, and back and shoulder muscle endurance showed significant positive changes [5]. This finding leads to the hypothesis that other outcome measures can be used to measure change in studies involving MT techniques. Of the 7 RCTs presented here, 4 used some subjective measure of quality of life or function [5, 10-12]. These outcome measures are important because they measure changes that the patient cares more about. Two of the studies also measured lung expansion, which can be an indicator of whether or not a patient is able to breathe easily $[10,11]$.

Future studies are needed to demonstrate the effectiveness of MT techniques for improvement of posture specifically in older adults (over age 60). Only 2 of the randomized controlled trials had a mean age over $60[5,12]$, and one of these did not find a significant change in posture after intervention. Just one out of 4 of the case studies were performed on an older adult. Therefore, it is not clear if the positive effects of manual therapy on posture are equally as significant in older populations, where the change in kyphosis is more pronounced.

\section{Conclusion}

This review found promising evidence for the use of manual therapy as a means to improve posture in adults. 11 of the 12 studies measuring postural improvement as an outcome measure showed a significant positive change in patients receiving manual therapy. The one RCT that did not find an improvement in posture over the control group did show significant changes in other outcome measures, including decreases in pain, improvement in physical function, and improvement in quality of life in the experimental group [5]. Outcome measures that may also be appropriate to show change include subjective measures of quality of life and physical functioning as well as lung function tests. These results demonstrate that even when postural gains are not made due to the use of manual therapy, other positive outcomes can still be seen that warrant the therapy. For the clinician seeking to help a patient improve their posture, manual therapy techniques can be an effective intervention that may also help improve their quality of life and physical functioning.

\section{References}

1. Kado DM (2009) The rehabilitation of hyperkyphotic posture in the elderly. European Journal of Physical and Rehabilitation Medicine 45: 583-593.

2. Staff MC Kyphosis. 20145 June 201420 September 2015]; Available from: http://www.mayoclinic.org/diseases-conditions/kyphosis/basics/definition/con20026732.

3. Fon GT, Pitt MJ, Cole Thies JA (1980) Thoracic kyphosis: range in normal subjects. American Journal of Radiology 134: 979-963.

4. Wendy B, Katzman P, DPTSc (2010) Age-related hyperkyphosis: its causes, consequences, and management. Journal of Orthopedic Sports Physical Therapy 40: $352-360$.

5. Bennell KL (2010) Effects of an exercise and manual therapy program on physical impairments, function and quality-of-life in people with osteoporotic vertebral fracture: a randomised, single-blind controlled pilot trial. BMC Muscluoskeletal Disorders 11: 36

6. Page MJ, Green S, Kramer S, Johnston RV, McBain B, et al. (2014) Manual therapy and exercise for adhesive capsulitis (frozen shoulder) (Review). Cochrane Database of Systematic Reviews (8): CD011275.

7. Gebremariam L (2014) Subacromial impingement syndrome effectiveness of physiotherapy and manual therapy. British Journal of Sports Medicine 48: 1202 1208.

8. French HP, Brennan A, White B, Cusack T (2011) Manual therapy for osteoarthritis of the hip or knee - a systematic review. Man Ther 16: 109-117. [crossref]
9. Christopher Kevin Wong P, OCS (2010) The effects of manual treatment on rounded-shoulder posture, and associated muscle strength. Journal of Bodywork \& Movement Therapies 14: 326-333.

10. Widberg K, Karimi H, Hafstrom I (2009) Self-and manual mobilization improves spine mobility in men with ankylosing spondylitis - a randomized study. Clinical Rehabilitation 23: 599-608.

11. Sandsund CA (2011) Musculoskeletal techniques for clinically stable adults with cystic fibrosis: a preliminary randomized controlled trial. Physiotherapy 97: 209217.

12. Ivan Bautmans P (2010) Rehabilitation using manual mobilization for thoracic kyphosis in elderly posmenopausal patients with osteoporosis. Journal of Rehabilitation Medicine 42: 129-135.

13. Jaehong Lee P (2013) The Effects of Cervical Mobilization Combined with Thoracic Mobilization on Forward Head Posture of Neck Pain Patients. Journal of Physical Therapy Science 25: 7-9.

14. Wontae Gong P (2015) The effects of cervical joint manipulation, based on passive motion analysis, on cervical lordosis, forward head posture, and cervical ROM in university students with abnormal posture of the cervical spine. Journal of Physical Therapy Science 27: 1609-1611.

15. Susan M, Roehrig P (2006) Use of neurodevelopmental treatment techniques in a client with kyphosis: A case report. Physiotherapy Theory and Practice 22: 337 343.

16. Si-Eun Park P, Joong-San Wang P (2015) Effect of joint mobilization using KEOMT and PNF on a patient with CLBP and a lumbar transitional vertebra: a case study. Journal of Physical Therapy Science 27: 1629-1632.

17. Staes FF (2009) Physical therapy as a means to optimize posture and voice parameters in student classical singers: A case report. Journal of Voice 23: 91-101.

18. Aaron LeBauer L, SDPT, Robert Brtalik S, Katherine Stowe S (2008) The effect of myofascial release (MFR) on an adult with idiopathic scoliosis. Journal of Bodywork \& Movement Therapies 12: 356-363.

19. Clare Lewis D, PsyD (2014) A preliminary study to evaluate postural improvement in subjects with scoliosis: active therapeutic movement version 2 device and home exercises using the Mulligan's mobilization-with-movement concept. Journal of Manipulative Physiol Ther 27: 502-509.

20. Sran MM, K.M. Khan (2006) Is spinal mobilization safe in severe secondary osteoporosis? - a case report. Manual Thearpy 11: 344-351.

21. Swinkels IC (2005) What factors explain the number of physical therapy treatment sessions in patients referred with low back pain; a multilevel analysis. BMC Health Services Research 5.

22. Struyf F, Nijs J, Mottram S, Roussel NA, Cools AM, et al. (2014) Clinical assessment of the scapula: a review of the literature. Br J Sports Med 48: 883-890. [crossref]

23. Barrett E, McCreesh K, J Lewis (2013) Intrarater and interrater reliability of the flexicurve index, flexicurve angle, and manual inclinometer for the measurement of thoracic kyphosis. Rehabilitation Research and Practice 2013: 7.

24. Harrison DE, Harrison DD, Cailliet R, Troyanovich SJ, Janik TJ, et al (2000) Cobb method or Harrison posterior tangent method: which to choose for lateral cervical radiographic analysis. SPINE 25: 2072-2078.

\section{Citation:}

Dudek E, Hughes L (2019) Manual Therapy Techniques and their Effectiveness on Improving Posture in Adults: A Narrative Review of the Literature. Integr J Orthop Traumatol Volume 2 (1): 1-5. 